\title{
Meckel Diverticulum
}

National Cancer Institute

\section{Source}

National Cancer Institute. Meckel Diverticulum. NCI Thesaurus. Code C12264.

A congenital pouch in the distal ileum. It may cause painless rectal bleeding and bowel obstruction. 